\title{
Listing in Special Corporate Governance Trading Segments and Accuracy of Analysts' Forecasts in Brazil
}

\author{
Miguel Carlos Ramos Dumer ${ }^{1} \&$ Antonio Lopo Martinez ${ }^{2}$ \\ ${ }^{1}$ Instituto Doctum, Brazil \\ ${ }^{2}$ Fucape Business School, Brazil \\ Correspondence: Antonio Lopo Martinez, Fucape Business School, Av. Fernando Ferrari, 1358, Boa Vista, \\ Vitória-ES CEP 29075-505, Brazil. Tel: 55-27-4009-4444. E-mail: lopo@ fucape.br
}

Received: August 25, 2015

doi:10.5539/ibr.v8n11p127
Accepted: September 7, 2015

Online Published: October 26, 2015

URL: http://dx.doi.org/10.5539/ibr.v8n11p127

\begin{abstract}
The aim of this article is to investigate whether there is a relationship between being listed in a trading segment of the BM\&FBovespa requiring enhanced corporate governance and the accuracy of analysts' forecasts. For this purpose, besides a literature review to establish the dependent and independent variables, we obtained data on the earnings per share estimated by analysts from the I/B/E/S database of Thomson Reuters and the actual figures one year after the forecast from the Economática database. We then used panel data regression with robust fixed effect, covering a period of 20 quarters (2007-1 to 2011-4). The results did not reveal a significant statistical relationship between listing in one of the three special trading segments of the BM\&FBovespa and the accuracy of analysts' forecasts.
\end{abstract}

Keywords: corporate governance, analysts, forecast errors, acuracy

\section{Introduction}

The Brazilian capital market has grown dramatically in the past two decades. During this period, the country's corporate governance practices have also developed significantly, both due to the deepening of the market and the improvement in the communication channels between market agents. The São Paulo Securities Exchange (BMF\&Bovespa) created three special listing segments designed for shares issued by companies that voluntarily undertake to abide by corporate governance practices and transparency requirements in additional to those already requested by the Brazilian Law and CVM (Brazilian Securities and Exchange Commission).

According to Lima (2009), among the objectives of the firms that adhere to these enhanced corporate governance levels is to reduce the information asymmetry among agents by establishing greater transparency regarding management practices. Therefore, it is reasonable to expect the resulting increased disclosure, one of the pillars of good corporate governance (Okimura, 2003; Lima, 2009), to have increased the accuracy of analysts' earnings forecasts. The aim of this study is hence to identify if there is a positive relation between being listed in one of the three enhanced governance segments of the BM\&FBovespa (Level 1, Level 2, and Novo Mercado) and the accuracy of analysts' predictions of earnings per share (EPS).

This article contributes to the understanding of the relationship between corporate governance practices, as a tool to encourage disclosure, and the behavior of analysts' forecasts in Brazil. It is relevant regarding both the literature on analyst and that on analysts' predictions. The various capital market agents (analysts, rating agencies, banks, stock exchanges, pension funds, investors, regulators, firms, and their managers, etc.) can benefit from identifying the impact on the accuracy of projections from adopting the governance levels required for listing in these special segments of the BM\&FBovespa.

For Saito, Villalobos, and Benetti (2008), investigation of the factors that influence analysts in their estimates are currently an important field of research. Martinez (2004) suggests studying "how firms' disclosure practices influence the performance of analysts' forecasts." In turn, Athanasakou, Strong, and Walker (2009) stress the importance of studying the real influence of corporate governance mechanisms on the quality of forecasts.

This paper differs from previous studies of the relationship of corporate governance and the accuracy of analysts' consensus earnings forecasts in Brazil (Dalmácio, 2009; Dalmácio, Lopes, \& Sarlo, 2010) by covering a more recent period. These previous studies analyzed the period between 2000 and 2008, while this one examines the 
period of 20 quarters of 2007 and 2011. During this interval, there was a change in the corporate accounting rules in Brazil to bring them into convergence with international rules (IFRS), through the enactment of Law 11,638/07, which amended Law 6,404/76 (the basic corporate law) (Lima, 2010; Santos \& Calixto, 2010). Among other effects, this changed investors' expectations regarding stock prices (Lima, 2010). Besides this, the period studied here includes the international crisis of 2008, which severely depressed equity prices in Brazil in the second half of the year.

\section{Literature Review}

\subsection{Information Asymmetry, Agency Problem, and Corporate Governance}

Akerlof (1970) demonstrated that information asymmetry between economic agents can reduce the volume of trading in the market. Jensen \& Meckling (1976) define the agency problem as the existence of a potential conflict of interest between principals (owners/stockholders) and the agents to whom they delegate powers to run firms (managers). Assuming that both these parties seek to maximize their own utility, there is reason to believe the agent will not always act in the interests of the principal. This is in contrast to the classic firm structure, where the principal (owner or majority stockholder) also acts as the agent (Lopes \& Martins, 2005). Indeed, this problem was identified as early as 1776 by Adam Smith, in his The Wealth of Nations, in commenting on the drawbacks of the joint stock company:

The directors of such companies, however, being the managers rather of other people 's money than of their own, it cannot well be expected, that they should watch over it with the same anxious vigilance which the partners in a private copartnery frequently watch over their own ... Negligence and profusion, therefore, must always prevail, more or less; in the management of the affairs of such a company.

In general, it is impossible for investors (principals) to watch over their agents (managers) at no cost, to assure that managers act in the best interests of investors. The agency cost is the sum of the expenses incurred by the principal to monitor the agent (Jensen \& Meckling, 1976). Theoretically, good corporate governance practices should reduce the agency cost (Shleifer \& Vishny, 1997). According to Silveira (2004), the incentive and control structure of well-governed corporations seeks to mitigate the costs arising from the agency problem, by reducing information asymmetry.

The information intermediaries, such as market analysts, help reduce this information asymmetry between managers and shareholders, allowing the capital market to function better (Iudícibus \& Lopes, 2002). Analysts are considered one of the main users of the information disclosed by firms (Silveira, 2004; Byard, Li, \& Weintrop, 2006), and good corporate governance enables them to do a better job of assessing this information and making accurate predictions about the future prospects of firms (Healy \& Palepu, 2001; Martinez, 2004).

For this study, our metric of good corporate governance practices is listing in one of the special segments of the BM\&FBovespa, under the assumption that this reduces information asymmetry and thus makes it more likely that analysts will be able to make accurate forecasts about these firms' future prospects.

\subsection{The Special Trading Segments of the BM\&FBovespa}

Corporate governance has developed significantly in Brazil during the past decade due to the growth of the capital market and the improvement in means of communication, as well as due to investors' demands. Another important factor was the creation of three special listing segments by the BM\&FBovespa in December 2000 (Level 1, Level 2, and Novo Mercado), an initiative inspired by similar developments in other countries, such as the Neuer Market in Germany (Nascimento, 2003). According to Okimura (2003), the creation of these new segments "established, by means of voluntary adhesion of new or already listed firms (...), superior levels of disclosure than those required by law." It should be noted that firms listed in the normal trading segment also often follow corporate governance practices beyond those required by law.

One of the main contributions of the differentiated corporate governance segments is suggested by Barbedo, Silva, and Leal (2009), in stating that "stock listing based on governance practices are used by securities exchanges to signal to investors greater protection against expropriation by controlling groups." They further state that the initiative taken by the BM\&FBovespa aimed to instill greater confidence in investors by the increased transparency, because the greater access to information makes it easier to price shares. These objectives are in line with the idea of reducing information asymmetry and the friction caused by the agency problem, facilitating the development of not only the stock market, but also the entire Brazilian economy.

Another impetus behind establishing these special listing segments, as mentioned by Dalmácio (2009), is based on signaling theory (Spence, 1973), according to which the voluntary adoption of the enhanced governance practices required for participation in one of these three segments is a way to send positive signals to the market. 
The author believes these signals influence analysts and are "parameters that change the conditional probability and define the beliefs, both of analysts in making their forecasts and recommendations and of investors in choosing their investments" (Dalmácio, Lopes, \& Sarlo, 2010).

While the signals sent by adhesion to a special listing segment act to reduce asymmetry among the various market agents, the interpretation of these signals by investors can be difficult and imprecise, so that analysts play the determining role for the market, due to their ability to note and interpret these signals.

Appropriate identification of research participants is critical to the science and practice of psychology, particularly for generalizing the findings, making comparisons across replications, and using the evidence in research syntheses and secondary data analyses. If humans participated in the study, report the eligibility and exclusion criteria, including any restrictions based on demographic characteristics.

\subsection{Market Analysts}

Market analysts act as financial intermediaries who reduce the information asymmetry between investors and firms (Iudícibus \& Lopes, 2002). Their job is to project results and make buy, sell or hold recommendations. For this purpose, they use as much information as is available, both formal and informal. According to Franco (2002), the considerations of analysts can be assumed as an upper limit to the analyses carried out by the various agents, since most investors do not have sufficient time or expertise to do these themselves, and thus rely on the reports prepared by analysts.

Bertucci, Bernardes, and Brandão (2006), in an empirical survey conducted among various capital market agents (company executives, portfolio managers, minority shareholders and directors of the Brazilian Association of Capital Market Investors, the Association of Capital Market Analysts and Investment Professionals, the Brazilian Corporate Governance Institute and the BM\&FBovespa), showed that the classification of companies according to their adhesion to enhanced corporate governance trading segments is one of the tools used by analysts to make their forecasts and recommendations. Therefore, besides relying on the accounting information required by law and information on the overall and sectorial economic environments, analysts also take into consideration the fact that firms belong to special trading segments.

However, analysts may not always be disinterested in their projections. Martinez (2004) classifies three main factors that can influence analysts in their predictions and recommendations. The first is remuneration: When a significant part of analysts' remuneration comes from commissions, it is possible they will tend to issue biased forecasts and recommendations, in such a way as to boost their commissions. The second factor is access to information, since their job depends on the quality and quantity of information obtained. For this, they use their relationships-formal and informal-with firm managers. These relationships can cause analysts to shy away from negative predictions so as not to undermine these relationships and the information access that comes with them. The third element is the effects on their reputation generated by efficacy. Analysts with good reputations generate a greater volume of transactions and hence commissions. Therefore, they are always interested in preserving and burnishing their professional reputations.

\subsubsection{Characteristics of Analysts' Projections}

Lang, Lins, and Miller (2003) state there is a consensus in the academic literature that the more precise analysts' projections are, the higher will be the value of the firms analyzed. In other words, precision contributes positively to firm value. Because of this relevance to the capital market, it is important to study analysts' forecasts.

Analysts used a range of tools to make their EPS estimates and their buy, sell or hold recommendations (Bertucci, Bernardes, \& Brandão, 2006). Studies of analysts' projections usually are based on their EPS forecasts, since it is easy to compare the projected and observed earnings, especially for listed companies. Other authors have tried to identify possible factors of the Brazilian market, such as the characteristics of firms and the information environment that can be related to errors and bias in EPS projections (Saito, Villalobos, \& Benetti, 2008).

Various studies have shown a relation between the accuracy of EPS forecasts and inherent factors of the company, such as size (Lang, Lins, \& Miller, 2003; Martinez, 2004; Bhate, Hope, \& Kang, 2006; Saito, Villalobos, \& Benetti, 2008; Dalmácio, 2009), result (profit or loss) in the quarter when the projection was made (Martinez, 2004; Bhat, Hope, \& Kank, 2006; Saito, Villalobos, \& Benetti, 2008; Dalmácio, 2009), and the ratio between the market and book price of the firm-price-to-book-(Richardson, Teoh, \& Wysocki, 1999; Martinez, 2004; Dalmácio, 2009; Dalmácio, Lopes, \& Sarlo, 2010).

Likewise, there are studies of the relationship between the EPS forecasts and the characteristics of analysts themselves, such as optimism (bias) of the forecast (Silva, 1998; Martinez, 2004; Dalmácio, 2009; Dalmácio, 
Lopes, \& Sarlo, 2010), among others. Finally, some studies have sought to understand the relationship of the accuracy of EPS predictions and the adhesion of companies to enhanced corporate governance practices, abroad (Bhat, Hope, \& Kank, 2006; Byard, Li, \& Weintrop, 2006) and in Brazil (Dalmácio, 2009; Dalmácio, Lopes, \& Sarlo, 2010; Dalmácio, Lopes, \& Rezende, 2010).

\section{Methodology}

To assess the possible relationship between corporate governance and the accuracy of analysts' forecasts in Brazil, we chose 94 companies listed for trading on the BMF and Bovespa, all of them participants of the Novo Mercado during 20 quarters (2007-1 to 2011-4). We obtained the data from the Institutional Brokers' Estimate System (I/B/E/S) of Thomson ONE Analytics as well as the Economática database. From these sources, it was possible to obtain data on the earnings per share (EPS) projections of analysts and the actual results attained by the firms, along with other financial and accounting information and the characteristics of each company analyzed. Finally, we obtained the information on the firms listed for trading in the Novo Mercado segment and the dates of joining from the BMF and Bovespa website. To capture the possible relationship of the explanatory variable (listing in a special corporate governance-trading segment) with the control variables and the dependent variable (accuracy), we used pooled data regression with panel data (Gujarati, 2006, for which it is necessary to use fixed effects.

\subsection{Database and Description of the Sample}

The original sample was composed of 352 firms listed on the BMF and Bovespa, some of them in one of the three special trading segments. We obtained accounting and financial data and EPS projections of analysts during the period from the first quarter of 2007 to the last quarter of 2011, covering a period of 20 quarters.

Table 1. Total companies excluded and included in the analysis

\begin{tabular}{ccc}
\hline Firms & Number & $\%$ \\
Excluded from the analysis & 213 & 60.5 \\
Included in the analysis & 139 & 39.5 \\
TOTAL & 352 & 100 \\
\hline
\end{tabular}

There were also some cases in which there was no information on the EPS realized in period $t$ with simultaneous availability of at least one EPS forecast in the previous period. We also eliminated these observations from the sample, leaving the final sample shown in Table 2 .

Table 2. Total observations by listing segment

\begin{tabular}{ccc}
\hline Quarterly Observations & Number & $\%$ \\
\hline Observations in Level 1 & 325 & 19.96 \\
Observations in Level 2 & 151 & 9.28 \\
Observations in Novo Mercado & 880 & 54.09 \\
Observations in the regular trading segment & 271 & 16.67 \\
TOTAL & 1627 & 100 \\
\hline
\end{tabular}

The initial research showed there was a reasonable number of firms without any analyst coverage available, and among those with coverage, this was not necessarily systematic. This does not mean these firms were not covered, because buy-side analysts could have done this.

\subsection{Research Problem}

From the data gathered, we tested the following hypothesis:

$\mathrm{H}$-There is a statistically significant and positive relation between listing in special corporate governance segments of the BM\&FBovespa and the accuracy of the consensus forecasts of analysts.

The main objective was to perceive whether an increase in disclosure due to the voluntary adherence to one of the special listing segments impacts the accuracy of market analysts' forecasts, since analysts are considered the main users of the information disclosed by publicly traded firms that adopt enhanced corporate governance practices (Bhat, Hope, \& Kank, 2006; Byard, Li, \& Weintrop, 2006) and the most able to interpret the signals 
sent (Franco, 2002).

\subsection{Variables}

\subsubsection{Dependent Variable}

The construct used as a proxy for accuracy was based on the model developed in the works of Martinez (2004) and Dalmácio (2009), as described below:

- $\quad$ ACC_N-Accuracy of the consensus forecast of analysts one year in advance.

The accuracy of the forecasting considers the size of the projection error, not its direction (too optimistic or pessimistic). Based on the model used by Martinez (2004) and Dalmácio (2009), we calculated the forecasting error by equation 1 below: the difference between the actual and predicted EPS divided by the absolute value of the actual EPS.

$$
\mathrm{FE}=\text { (actual EPS-forecast EPS)/ |actual EPS| }
$$

From this, we calculated the mean of the forecasting errors (Equation 2) to ascertain the existence of bias in the predictions:

$$
M F E=(1 / n) \times \sum_{i=0}^{n} F E
$$

Then we calculated the mean of the absolute value of the forecasting errors (Equation 3) to find the accuracy of analysts' forecasting errors. In other words, the smaller the value of MAFE (mean absolute forecasting error), the greater the accuracy, configuring an inverse relation.

$$
M A F E=(1 / n) \times \sum_{i=0}^{n}|F E|
$$

By multiplying MAFE by (-1) it is possible to obtain from the independent variables results that increase when the prediction accuracy is greater, that is, to obtain from the coefficients of the independent variables results with negative signs when the accuracy declines, and positive signs when the accuracy increases.

$$
A C C_{-} N=(-1) \times M A F E
$$

\subsubsection{Independent Explanatory Variables of the Accuracy of Analysts' Forecasts}

By searching the sites of the BM\&FBovespa and the Brazilian Securities Commission (CVM) it was possible to identify the dates when the firms in the sample adhered to one of the listing segments requiring enhanced corporate governance, enabling verification of the effects of this adhesion on the accuracy of the consensus forecasts of those companies. For this purpose, we used the following explanatory variables:

- DL1-dummy variable to capture whether the forecasts were made in quarters when the company belonged to the Level 1 trading segment.

- DL2-dummy variable to capture whether the forecasts were made in quarters when the company belonged to the Level 2 trading segment.

- DNM-dummy variable to capture whether the forecasts were made in quarters when the company belonged to the Novo Mercado trading segment.

In all cases, the dummy variable takes on the value of 1 in quarters when the company was listed for trading in one of the three enhanced corporate governance trading segments, and 0 otherwise. These explanatory variables are the same as those used by Dalmácio (2009) and Dalmácio, Lopes, and Sarlo Neto (2010).

Here we assume that a firm adhesion to one of the special listing segments of the BM\&FBovespa will mean a higher level of disclosure (Okimura, 2003), which should have a significant positive influence on the accuracy of analysts' forecasting errors.

\subsubsection{Control Variables}

The purpose of the control variables is to isolate the effect on the dependent variable. We chose seven such variables, based on the review of another article on the same theme. They are:

- NUMAN-Number of analysts making predictions about each company.

This variable indicates the number of analysts that followed firm $i$ in period t. various studies have identified a positive relation between the number of analysts who follow a given firm and the quality of their forecasts (Hope, 2003; Martinez, 2004; Saito, Villalobos, \& Benetti, 2008, Dalmácio, 2009).

- $\quad$ SIZE-Natural logarithm of the total assets of each firm in the quarter when the forecast was issued.

This variable captures the influence of the firm's internal conditions. For this, we used the total assets in each 
quarter, obtained from the Economática database. Again, several studies have identified a relation between firm size and the accuracy of earnings predictions (Martinez, 2004; Chiang \& Chia, 2005; Bhat, Hope, \& Kank, 2006; Saito, Villalobos, \& Benetti, 2008; Dalmácio, 2009). Lang, Lins, and Miller (2003) argued that the larger the company, the more dispersed and complex its business activities will tend to be, making it harder for analysts to do their job and thus increasing the chance of errors. In contrast, Hope (2003) argued that larger firms have a greater amount of public information, improving the informational environment and diminishing analysts' errors.

- DOBSRES-Dummy variable that captures information on the firm's observed result in the quarter when the forecast was issued.

This explanatory variable represents the result (profit or loss) in the quarter when the forecast was made. It takes on the value of 1 when the result is loss and 0 when the result is profit. There is evidence that earnings predictions are less accurate in periods when firms are running in the red (Martinez, 2004; Bhat, Hope, \& Kank, 2006; Saito, Villalobos, \& Benetti, 2008; Dalmácio, 2009).

- $\quad$ PTB (price-to-book)-ratio between the market price and the book value.

Stocks with low PTB ratios (an indicator of value stocks) have performed worse in the recent past than those with high PTB (growth stocks). Investors tend to react pessimistically to a situation of low PTB and optimistically to a situation of high PTB. This is because investors base their expectations for future growth on past performance (Fama \& French, 1996). By acquiring shares at a low price in relation to the book value of equity, they should theoretically have greater returns (better upside).

A number of articles have shown that analysts tend to be better at predicting future earnings of firms with high price-to-book ratios (Richardson, Teoh, \& Wysocki, 1999; Martinez, 2004).

- DOPTIM-Dummy variable that contemplates the bias of analysts (optimistic or pessimistic).

It assumes the value of 1 for predictions with optimistic bias and 0 for those with pessimistic bias. Silva (1998) and Martinez (2004) found a positive relation between optimistic bias and accuracy, in contrast to Dalmácio (2009). An optimistic bias occurs when the EPS forecast by the analysts is greater than that observed in practice, to the contrary applying to pessimistic bias. In other words, this variable accounts for the direction of the error (positive or negative), while the accuracy only takes into account the size of the error, not whether it is positive or negative.

- Quarter Dummies-Dummy variables that capture the peculiarities of each quarter.

These assume the value of 1 for a determined quarter and 0 for other quarters. The aim is to capture and isolate the possible effects of occurrences in these periods that can influence the results of the companies and the perception of analysts. Various other studies have used these control variables (Saito \& Villalobos; Benetti, 2008; Dalmácio, 2009).

- Sector Dummies-Dummy variables that capture the peculiarities of each economic sector defined in the Economática database.

These assume the value of 1 for companies in each of the defined economic sectors and 0 for firms in other sectors. This type of control variable was also used by Saito, Villalobos, and Benetti (2008) and Dalmácio (2009). If interventions or experimental manipulations were used, provide evidence on whether they were delivered as intended. In basic experimental research, this might be the results of checks on the manipulation. In applied research, this might be, for example, records and observations of intervention delivery sessions and attendance records.

\subsection{Presentation of the Regression Model}

The regression model used to analyze the impact of the independent variables on the dependent variable can be represented by the following equation:

Where:

$$
A C C_{-} N=\alpha_{0}+\alpha_{1} D L 1_{i t}+\alpha_{2} D L 2_{i t}+\alpha_{3} D N M+\sum_{j}^{k} \omega_{j} C V_{j t}+\partial_{I}+\varepsilon_{i t}
$$

ACC_ $\mathrm{N}_{\mathrm{it}}$ represents the accuracy of the consensus forecast of analysts for firm $i$ in period $t$, as used by Martinez (2004) and Dalmácio (2009); DL1, DL2, and DNM respectively represent the independent dummy variables for adhesion to the Level 1, Level 2, and Novo Mercado trading segments by firm $i$ in period $t ; V C_{j t}$ is composed of the control variables $j$, of a total of $k$ variables for firm $i$ in period $t$; $\delta_{\mathrm{i}}$ represents the specific unobservable effects for firm $i$; $\mathrm{e}_{\mathrm{it}}$ represents the random error for firm $i$ in period $t$; and the coefficients $\alpha_{1}, \alpha_{2}$, and $\alpha_{3}$ represent the relationship between adhesion to the Level 1, Level 2, and Novo Market trading segments, respectively. 
If the value found for these coefficients is statistically significant and positive, the analysts that follow these firms, while a negative value indicates a reduction in accuracy can assume it.

\section{Tests and Analysis of the Data}

\subsection{Descriptive Statistics and Correlation between the Variables}

The descriptive statistics of the variable utilized are presented below.

Table 3. Descriptive statistics of the variables

\begin{tabular}{cccccc}
\hline Variable & Observations & Mean & Standard Deviation & Min. & Max. \\
\hline ACC_N & 1627 & -1.09844 & 4.03863 & -84.4826 & -0.00066 \\
DL1 & 1627 & 0.19975 & 0.39994 & 0 & 1 \\
DL2 & 1627 & 0.09281 & 0.29025 & 0 & 1 \\
DNM & 1627 & 0.54087 & 0.49848 & 0 & 1 \\
NUMAN & 1627 & 2.20221 & 1.46263 & 1 & 12 \\
DOPTIM & 1627 & 0.85618 & 0.35102 & 0 & 1 \\
SIZE & 1627 & 15.6084 & 1.65909 & 9.86365 & 20.50364 \\
DOBSRES & 1627 & 0.098611 & 0.298243 & 0 & 1 \\
PTB & 1627 & 3.80953 & 6.959911 & -15.2 & 117.6 \\
\hline
\end{tabular}

From the data presented in Table 3, the accuracy metric (ACC_N) shows a significant distance between the values individually predicted by analysts and those actually realized by the firms. Table 4 presents an acceptable situation of pairwise correlation between the variables.

Table 4. Correlations between the variables

\begin{tabular}{ccccccc}
\hline & ACC_N & NUMAN & DOPTIM & SIZE & DPRJ & PTB \\
\hline ACC_N & 1 & & & & & \\
NUMAN & -0.107 & 1 & & & & \\
DOPTIM & 0.2393 & 0.107 & 1 & & & \\
SIZE & -0.155 & 0.3802 & 0.0951 & 1 & & \\
DPRJ & -0.0084 & -0.0891 & -0.2569 & -0.1218 & 1 & \\
PTB & 0.0311 & 0.0661 & 0.0543 & -0.128 & -0.0714 & 1 \\
\hline
\end{tabular}

\subsection{Results and Analysis}

We used panel data analysis with fixed effects, based on the results of both the Hausman and Breusch-Pagan tests. We also performed panel data regression with random effects and did not identify significant differences between the coefficients. The result of the Hausman indicated $\mathrm{Chi}^{2}$ of 0.22 , a non-significant value, failing to reject the null hypothesis of systematic differences between the coefficients of these two estimators. Therefore, it can be assumed that the estimation of the model with random effects provides similar results.

We did not identify serious problems of multicollinearity when analyzing the variance inflation factors, and the pairwise correlations between the explanatory variables were not significant, as shown in Table 4 . The highest correlation was -0.2569 , between DOBSRES and DOTIN.

Table 5 shows the result of the regression of the model chosen, after these preliminary tests, with the accuracy of analysts' consensus projections as the dependent variable (ACC_N), to test whether this is influenced by adhesion of the firm to one of the enhanced corporate governance trading segments of the BM\&FBovespa.

The null hypothesis that the coefficients together are equal to zero was rejected by the F-statistic. According to the robust fixed effects approach, the value of 44.62 was significant at $1 \%$. 
Table 5. Regression-panel data-fixed effects

\begin{tabular}{cccc}
\hline Variables & Coefficients & $\mathrm{t}$ & $\mathrm{P}>[\mathrm{t}]$ \\
\hline DL1 & 0.475396 & 1.15 & 0.249 \\
DL2 & $3.50048^{* * *}$ & 7.23 & 0.000 \\
DNM & $0.84887^{* *}$ & 2.59 & 0.010 \\
\hline Control Variables & & & \\
\hline NUMAN & -0.011739 & -0.24 & 0.813 \\
DOPTIM & $1.030608^{* * *}$ & 5.87 & 0.000 \\
SIZE & $-0.43045^{* *}$ & -2.380 & 0.017 \\
DOBSRES & -0.022986 & -0.01 & 0.990 \\
PTB & 0.02058 & 0.17 & 0.862 \\
Quarter Dummies & Yes & Yes & Yes \\
Sector Dummies & - & - & - \\
\hline Observations & 1627 & & \\
F-Statistic & $46.12^{* * *}$ & &
\end{tabular}

Notes.

(1) The asterisks indicate the level of significance of the coefficients: ***(lower than $1 \%)$, **( lower than 5\%) and *(lower than $10 \%)$.

(2) For the quarter and sector dummies, "Yes" means at least one was significant, and "No" the opposite.

(3) The panel data regression with random effects produced similar coefficients to that with fixed effects, according to the Hausman test.

(4) The pooled model is not reported because it did not consider the unobservable factors that could influence the relationship between the adoptions of enhanced corporate governance practices and the accuracy of analysts' forecasts.

(5) The model ACC_ $N=\alpha_{0}+\alpha_{1} D L 1_{i t}+\alpha_{2} D L 2_{i t}+\alpha_{3} D N M+\sum \omega_{j} C V_{j t}+\partial_{I}+\varepsilon_{i t}$.

Although the results shown in Table 5 were promising and confirmed in general they research hypothesis, we applied the Wald test with fixed effects, which identified a problem of heteroskedasticity of the error terms. The models also presented serial correlation of the errors, indicated by the test developed by Wooldridge (2010) for linear models with panel data. The test of Petersen (2009) for correlation of the error terms between units of analysis or years could not be applied due to the high imbalance of the panel data.

According to Fávero (2013), there is often a lack of care regarding the criteria for choosing one model over another one, as well as an absence of detailed discussion of the possible estimators to be studied in each situation in works on accounting and finance in Brazil.

To correct for the problems mentioned previously, including the possible correlation between the error terms of different units, we calculated the models with robust errors between the quarters (clustered robust errors) according to Petersen (2009). We used the robust regression method because it "seeks to detect and correct situations of heteroskedasticity of the perturbation terms" (Fávero et al., 2009).

The results are presented in Table 6. 
Table 6. Regression-panel data-fixed effects-clustered robust standard error

\begin{tabular}{llll}
\hline Variables & Coefficients & $\mathrm{t}$ & $\mathrm{P}>[\mathrm{t}]$ \\
\hline DL1 & 0.4753 & 0.85 & 0.398 \\
DL2 & 3.50048 & 1.19 & 0.234 \\
DNM & 0.84887 & 1.08 & 0.281 \\
\hline Control Variables & & & \\
\hline NUMAN & -0.011739 & -0.54 & 0.555 \\
DOPTIM & $0.96041^{* * *}$ & 4.92 & 0.000 \\
SIZE & -0.4304 & -1.61 & 0.111 \\
DOBSRES & -0.022986 & -0.02 & 0.986 \\
PTB & 0.02058 & 0.40 & 0.692 \\
Quarter Dummies & Yes & Yes & Yes \\
Sector Dummies & - & - & - \\
\hline Observations & 1627 & & \\
F-Statistic & $3.25^{* * *}$ & & \\
\hline
\end{tabular}

Notes.

(1) The asterisks indicate the level of significance of the coefficients: ***(lower than $1 \%)$, **( lower than $5 \%)$ and *( lower than $10 \%)$.

(2) For the quarter and sector dummies, "Yes" means at least one was significant, and "No" the opposite.

(3) Fixed-effect regression with clustered robust standard errors. The estimated coefficients can be correlated with the regressors, permitting a limited form of endogeneity. The errors are assumed independent between the individual observations and the error is assumed heteroscedastic.

According to the result of the panel data regression with fixed effects and clustered robust standard errors, it is not possible affirm there is a statistically significant relationship between the dependent variable ACC_N and the independent variables DL1, DL2, and DNM, so the research null hypothesis cannot be rejected. In other words, it is not possible to say there is a statistically significant relation between the accuracy of analysts' EPS forecasts of firms listed for trading in one of the special corporate governance segments of the BM\&FBovespa between the first quarter of 2007 and the last quarter of 2011.

This result partly agrees with those of Dalmácio (2009), who also used data on forecasts from the I/B/E/S base. The variables representing Level 1 and Level 2 show similar results, with positive but non-significant coefficients. However, she found a positive and significant result in the explanatory variable of the Novo Mercado segment (that requiring the highest level of corporate governance). In contrast, while we also found a positive result in this respect, it was not significant. Nevertheless, her study covered the nine-year period between 2000 and 2008 while we analyzed 20 quarters between 2007 and 2011.

There are two possible explanations for this difference in findings. The first is the international crisis, which severely depressed the prices of firms listed on the BM\&FBovespa, particularly in the last quarter of 2008, causing "the stock of assets to be undermined by capital flight" (Gentil \& Maringoni, 2009). The second is the changes in corporate accounting standards introduced by Law 11, 638/07, which amended the Law of Corporations (Law 6, 404/76) to bring Brazilian accounting standards into convergence with international standards (IFRS). This caused significant changes in the disclosure of information by listing companies starting in 2008 (Lima, 2010; Santos \& Calixto, 2010), also triggering alterations in investors' expectations and in stock prices (Lima, 2010). Antunes et al. (2012) pointed out that market analysts were among the agents that felt the main impacts of these alterations. According to Aubert and Dumontier (2010), analysts were unable to anticipate the consequences of the adoption of IFRS. This might have made forecasting more difficult to analysts became familiar with the new standards. According to Beuselink et al. (2010), although mandatory adoption of IFRS tends to improve the processing of information by analysts, this effect is not homogeneous across all analysts.

The only control variable that was significant (1\%) was DOPTIM, responsible for identifying the impact of optimistically biased forecasts. It obtained a positive sign, indicating a direct relationship between optimistic forecasts and accuracy. This result corroborates those found by Martinez (2004) but runs counter to those found by Dalmácio (2009), who found a negative relation. According to Martinez (2004), "analysts will be relatively optimistic or pessimistic depending on the aspects related to their personality." Further, according to him, the optimism or pessimism of analysts can also be related to external factors, such as economic circumstances and political factors. Consequently, it is hard to specify a possible reason, but there was a deep economic crisis in the second half of 2008, extending into early 2009. According to the results found here, the pessimistic predictions appear to reflect exaggerated foreboding. 
The variables NUMAN, SIZE, DOBSRES and PTB, which respectively represent the number of analysts covering a firm in the period, the size of the firm's assets, a dummy that identifies loss in the period when the forecast was issued and the price-to-book ratio, were not statistically significant. Besides this, some of the dummy variables used to control for temporal effects were statistically significant.

\section{Conclusion}

This article sought to answer the following question: Is there a positive and significant relationship between listing in trading segments requiring enhanced corporate governance and the accuracy of analysts' consensus forecasts for earnings per share in the Brazilian market?

Based on the theoretical-empirical model developed and the robust statistical analysis, the conclusion is that it is not possible to identify a statistically significant relation between the dependent variable-analysts' consensus forecasts-and the explanatory variables of adhesion to the Level 1, Level 2, and Novo Mercado trading segments.

There are two possible (and not mutually exclusive) explanations for this result. One is the international crisis that began in the second half of 2008. This could have influenced the accuracy of predictions, since "the projections of results by analysts are very sensitive to market expectations, economic circumstances and even political factors (...)" (Martinez, 2004). The second is the requirement to adopt IFRS that was phased in starting in 2008 under the amendments to Law 6,404/76 introduced by Law 11,638/07, causing significant changes in the accounting information disclosed to the market (Lima, 2010; Santos \& Calixto, 2010). According to Antunes et al. (2012), analysts were among the agents that most felt the impacts of these changes, which could have reduced the accuracy of their forecasts.

In the econometric model applied, only the control variable DOPTIM, which reflects the bias of analysts' forecasts, was significant (at 1\%) with positive sign, indicating a positive bias. This result corroborates those found by Martinez (2004).

Among the limitations of this study is the relatively small sample of firms. However, we believe the sample is substantially representative of the composition of the BMF and Bovespa and we included all the firms for which it was possible to obtain data from Thomson Reuters I/B/E/S, along with the corresponding data on actual results from the financial statements from the Economática database. But there could have been measurement errors resulting from the classification criteria adopted by each information source.

Based on the evidence presented here, it can be inferred that for the period from 2007 to 2011, the fact of being listed in a special trading segment of the BM\&FBovespa did not assure a better quality of the information disclosed to the market, at least when measured by the accuracy of analysts' earnings projections. Further research is in order to investigate some of the themes discussed here, to gain a better understanding of the corporate governance mechanisms that are most effective in improving the accuracy of analysts' forecasts, particularly the effects of the changes in accounting standards in Brazil and of the recent economic crises.

\section{References}

Akerlof, G. A. (1970). The market for "lemons": Quality uncertainty and the market mechanism. Quarterly Journal of Economics, 84(3), 488-500. Retrieved from http://www.jstor.org/stable/1879431

Antunes, M. M. T. P., Grecco, M. C., Formigoni, P. H., \& Neto, O. R. M. (2012). A adoção no Brasil das normas internacionais de contabilidade IFRS: O processo e seus impactos na qualidade da informação Contábil. Revista de Economia e Relações Internacionais-FAAP, São Paulo, 10(20), 5-20.

Athanasakou, V. E., Strong, N. C., \& Walker, M. (2009). Earnings management or forecast guidance to meet analyst expectations? Accounting and Business Research, 39(1). 3-35. http://dx.doi.org/10.1080/00014788.2009.9663347

Aubert, F., \& Dumontier, P. (2009). Analyzing brokers' expertise: Did analysts fully anticipate the impact of IFRS adoption on earnings? The European evidence. Working paper. http://dx.doi.org/10.2139/ssrn.1420035

Barbedo, C. H., Silva, E. C., \& Leal, R. P. C. (2009). Probabilidade de informação privilegiada no mercado de ações, liquidez intra-diária e níveis de governança corporativa. Revista Brasileira de Economia. Rio de Janeiro, 63(1), 51-62. http://dx.doi.org/10.1590/s0034-71402009000100004

Bertucci, J. L. O., Bernandes, P., \& Brandão, M. M. (2006). Políticas e práticas de governança corporativa em empresas brasileiras de capital aberto. R. Adm., São Paulo, 41(2), 183-196.

Bhat, G., Hope, O., \& Kang, T. (2006). Does corporate governance transparency affect the accuracy of analyst 
forecast? Accounting and Finance, 46(5), 715-732. http://dx.doi.org/ 10.1111/j.1467-629X.2006.00191.x

Beuselink, C., Joos, P., Khurana, I., \& Vanden, M. S. (2010). Mandatory adoption of IFRS and analysts' forecasts information properties. Working Paper. Retrieved from http://ssrn.com.abstract=1705402

Byard, D., Li, Y., \& Weintrop, J. (2006). Corporate governance and the quality of financial analysts' information. Journal of Accounting and Economics, 25(5), 609-625. http://dx.doi.org/10.1016/j.jaccpubpol.2006.07.003

Dalmácio, F. Z. (2009). Mecanismos de governança e acurácia das previsões dos analistas do mercado brasileiro: uma análise sob a perspectiva da teoria da sinalização. 2009. 241 f. Tese (Doutorado em Contabilidade)-Faculdade de Economia, Administração e Contabilidade, Universidade de São Paulo, São Paulo.

Dalmácio, F. Z., Lopes, A. B., \& Sarlo, N, A. (2010). Uma análise da relação entre governança corporativa e acurácia das previsões dos analistas do mercado brasileiro. In: ASSOCIAÇÃO NACIONAL DOS PROGRAMAS DE PÓS-GRADUAÇÃO EM CIÊNCIAS CONTÁBEIS (ANPCONT), 4., Natal (RN). Anais... Natal: ANPCONT.

Dalmácio, F. Z., Lopes, A. B., \& Rezende, A. J. (2010). Governança corporativa e acurácia das previsões individuais dos analistas: Uma análise no mercado brasileiro. In: Congresso USP de Controladoria e Contabilidade, 10 ed., 2010, São Paulo (SP). Anais... São Paulo: USP.

Fama, E., \& French, K. (1996). Multifactor explanations of asset pricing anomalies. Journal of Finance, 51(1), 55-84. http://dx.doi.org/10.1111/j.1540-6261.1996.tb05202.x

Fávero, L. P., Belfiore, P., Silva, F. L., \& Chan, B. L. (2009). Análise de dados: Modelagem multivariada para tomada de decisões. Rio de Janeiro: Elsevier.

Fávero, L. P. (2013). Dados em Painel em Contabilidade e Finanças: Teoria e aplicação. Brazilian Business Review, 10(1).

Franco, D. (2002). Projeções de lucros sistematicamente exagerados: Um estudo para o Brasil. Revista Brasileira de Economia, Rio de Janeiro, 56(4), 591-603.

Gentil, D. L., Maringoni, G. (2009). Crise econômica e condicionantes externos e internos. In. Bispo, C. R. Musse, J. S. Vaz, F. T. Martins, F. J. (Org.) Crise financeira mundial: impactos sociais e no mercado de trabalho. Brasília: ANFIP.

Gujarati, D. (2006). Econometria Básica. Rio de Janeiro: Elsevier.

Iudicibus, S., \& Lopes, A. B. (2002). De volta para o futuro: Óbito presumido e outros mitos que habitam o castelo da contabilidade. UnB Contábil. Brasília, 6(2), 53-60.

Jensen, M., \& Meckling, W. (1976). Theory of the firm: Managerial behavior, agency costs, and ownership $\begin{array}{lllll}\text { structure. Journal of } & \text { Financial } & \text { Economics. } & 3(4), & \text { 305-360. }\end{array}$ http://dx.doi.org/10.1016/0304-405X(76)90026-X

Healy, P. M., \& Palepu, K. G. (2001). Information asymmetry, corporate disclosure, and the capital markets: A review of the empirical disclosure literature. Journal of Accounting and Economics, 31(1-3), 405-440. http://dx.doi.org/10.1016/S0165-4101(01)00018-0

Hope, O. K. (2003). Disclosure practices, enforcement of accounting standards, and analysts forecast accuracy: An international study. Journal of Accounting Research. 41(2), 235-272. http://dx.doi.org/10.1111/1475-679X.00102

Lang, M. H., Lins, K. V., \& Miller, D. P. (2003). ADRs, analysts, and accuracy: Does cross listing in the United States improve a firm's information environment and increase market value? Journal of Accounting Research, 41(2), 317-345. http://dx.doi.org/10.1111/1475-679X.00106

Lima, G. A. S. F. (2009). Nível de evidenciação X custo da divida das empresas brasileiras. Revista Contabilidade \& Finanças, USP, 20(49), 95-108. http://dx.doi.org/10.1590/S1519-70772009000100007

Lima, J. B. N. (2010). A relevância da informação contábil e o processo de convergência para as normas IFRS no Brasil. 2010. 244 f. Tese (Doutorado em Ciências Contábeis)-Programa de Pós-Graduação em Controladoria e Contabilidade, FEA/USP, São Paulo.

Lopes, A. B., \& Martins, E. (2005). Teoria da contabilidade: Uma nova abordagem. São Paulo: Atlas.

Martinez, A. L. (2004). Analisando os analistas: Estudo empírico das projeções de lucros e das recomendações dos analistas de mercado de capitais para as empresas brasileiras de capital aberto. 2004. p. 234. Tese 
(Doutorado em Administração de Empresas)-Escola de Administração de Empresas de São Paulo, Fundação Getúlio Vargas, São Paulo.

Nascimento, L. C. (2003). Governança Corporativa: Um estudo do efeito da adesão das empresas de capital aberto às práticas de governança da Bovespa sobre o valor de suas ações. 2003. 110 f. Dissertação (Mestrado em Admistração)-aculdade de Economia, Administração e Contabilidade da Universidade de São Paulo.

Okimura, A, R. T. (2003). Estrutura de propriedade, governança corporativa, valor e desempenho das empresas no Brasil. 2003. p. 120. Dissertação (Mestrado em Administração)-Faculdade de Economia, Administração e Contabilidade. Universidade de São Paulo, São Paulo.

Petersen, M. A. (2009). Estimating standard errors in finance panel data sets: Comparing approaches. The Review of Financial Studies, 22(1). http://dx.doi.org/10.1093/rfs/hhn053

Richardson, S. A., Teoh, S. H., \& Wysocki, P. D. (1999). Tracking analysts'forecasts over the annual earnings horizon: Are analysts' forecasts optimistic or pessimistic? Working Paper. University of Michigan. http://dx.doi.org/10.2139/ssrn.168191

Saito, R., Villalobos, S. J., \& Benetti, C. (2008). Qualidade das projeções dos analistas sell-side: Evidência empírica do mercado Brasileiro. Rausp, 43(4), 356-369.

Santos, E. S., \& Calixto, L. (2010). Impactos do início da harmonização contábil internacional (lei 11.638/07) nos resultados de empresas abertas. RAE-eletrônica, 9(1).

Shleifer, A., \& Vishny, R. W. (1997). A survey of corporate governance. Journal of Finance, 52, 737-738. http://dx.doi.org/10.1111/j.1540-6261.1997.tb04820.x

Silveira, A. M. (2004). Governança corporativa e estrutura de propriedade: determinantes e relação de desempenho das empresas no Brasil. 2004. p. 254. Tese (Doutorado em Administração)-Faculdade de Economia, Administração e Contabilidade, Universidade de São Paulo, São Paulo.

Wooldridge, J. M. (2010). Econometric Analysis of Cross Section and Panel Data. Cambridge: MIT Press.

\section{Copyrights}

Copyright for this article is retained by the author(s), with first publication rights granted to the journal.

This is an open-access article distributed under the terms and conditions of the Creative Commons Attribution license (http://creativecommons.org/licenses/by/3.0/). 